二段環境下の腐食疲労寿命 ${ }^{\dagger}$

\author{
岡田庸 敬* 服部: 修 次* 水島 憲 行**
}

\title{
Corrosion Fatigue of Carbon Steel under Torsional \\ Load in Two-Stage Tests
}

by

\section{Tsunenori OkadA*, Shuji HatTori* and Noriyuki Mizushima**}

Two-stage corrosion-fatigue life tests in $3 \% \mathrm{NaCl} \rightleftarrows$ laboratory air, $3 \% \mathrm{NaCl} \rightleftarrows$ ion exchanged water, and $3 \% \mathrm{NaCl} \rightleftarrows 0.5 \% \mathrm{NaCl}$ conditions were performed under torsional load, and the results were discussed based on the observation of cracks on the axial section of test pieces. The following conclusions were drawn:

(1) For the test of $3 \% \mathrm{NaCl} \rightarrow$ laboratory air, the fatigue life was reduced remarkably and the total number of stress cycles to failure became shorter than that for the continuous $3 \% \mathrm{NaCl}$ condition. A similar tendency was obtained for the tests of $3 \% \mathrm{NaCl} \rightarrow$ ion exchanged water, and $3 \% \mathrm{NaCl}$ $\rightarrow 0.5 \% \mathrm{NaCl}$. However, the reduction of fatigue life was slight because the damage in the first stage was not so severe as that for the test of $3 \% \mathrm{NaCl} \rightarrow$ laboratory air.

(2) For the reverse tests, i.e. laboratory air $\rightarrow 3 \% \mathrm{NaCl}$, ion exchanged water $\rightarrow 3 \% \mathrm{NaCl}$, and $0.5 \% \mathrm{NaCl} \rightarrow 3 \% \mathrm{NaCl}$, the fatigue lives followed Miner's law.

(3) After the corrosion environment was changed to less corrosive one, a few cracks among many short cracks having appeared in the first stage grew acceleratedly and led to a shorter life. For the reverse case, most of the cracks propagated in the second stage, and the life was predictable by the Miner's law.

キー・ワード : 腐食疲労, 炭素鋼, 二段環境, 水じり荷重

\section{1 緒言}

海洋構造物, 船舶, 橋梁, 航空機など戸外で使用さ れる機械, 構造物は大気環境のほかに海水, 雨水など 種々の環境の繰返しにさらされている。しかし，構造 用材料の腐食疲労の研究は多くの場合一定環境下で行 われ，環境の変動に対して，泀とんど考慮されていな いのが現状である.

環境の変動に対する従来の研究は主として液中と大 気中の二段環境下で行われ，古くは McAdam により， 第 1 段階で腐食疲労を与兄たのち第 2 段階で空中の疲 労試験を行い, 腐食疲労による食孔あるいはき裂が強 度に及ぼす影響として種々の応力繰返し速度について 第 1 段階による被害を求めた. Evans と Simnad は 第 1 段環境を適当な長さにとると腐食環境中のみの場 合よりも寿命が低下することを見出し，腐食環境中で は多数のき裂が発生し, 破壊に寄与する主き裂の応力 集中を緩和するためであるとしている. Rollinsらも同 様に二段環境下で瘦労寿命が低下する傾向を報告して 特り，水溶液中では酸素が供給されにくいのでき裂の 進展が大気中よりも遅かったためであると述べている. さらに, 北川ら, 遠藤らも同様な傾向を得て, 両環境
中のき裂進展速度の相違から説明している.

以上のよらに二段環境に関する研究といっても腐食 環境中と大気中の環境変化についてのものが臣とんど で, 他の環境条件の組合せ，たとえば濃度，温度など を変化させた場合についてはほとんど報告されていな い. 特に腐食性環境中から大気中へ切換えた場合, あ る試験条件下では腐食性環境中の疲労寿命よりも更に 低い疲労寿命を示すが，こうした寿命低下は腐食性の 異なる環境の組合せに和いても生じることが考えられ る. 本報では大気中の疲労強度よりも低い応カレベル で，3\%食塩水中から大気中や濃度の異なる食塩水中 へ切換光る場合も含めて広範团に二段環境のねじり疲 労試験を行い, 断面のき裂観察などから検討を加えた.

\section{2 供試材料および試験方法}

供試材料は機械構造用炭素鋼 S 35 C で, 化学成分を Table I に示寸. 材料は最初 $865^{\circ} \mathrm{C}$, 30分間保持後空 冷の焼ならし処理を施したのち，Fig. 1 に示す試験片 形状に機械加工し，平滑部およびフィレット部を\#6/0 エメリー紙で研摩した. その後, $600{ }^{\circ} \mathrm{C}, 30$ 分間真空 焼なまし処理をし，試験直前にアルコールとアセトン で十分に洗浄したのち試験に供した．熱処理後の機械

†原稿受理・昭和60年1月10日 Received Jan. 10, 1985

* 正 会員 福井大学工学部 福井市文京, Faculty of Engineering, Fukui University, Bunkyo, Fukui

** 福井村田製作所(株) 武生市岡本町, Fukui-Murata Co., Okamoto-cho, Takefu 
Table I. Chemical composition of material (\%).

\begin{tabular}{c|c|c|c|c|c|c|c}
\hline $\mathrm{C}$ & $\mathrm{Si}$ & $\mathrm{Mn}$ & $\mathrm{P}$ & $\mathrm{S}$ & $\mathrm{Cu}$ & $\mathrm{Ni}$ & $\mathrm{Cr}$ \\
\hline 0.37 & 0.24 & 0.77 & 0.019 & 0.023 & 0.01 & 0.02 & 0.04 \\
\hline
\end{tabular}

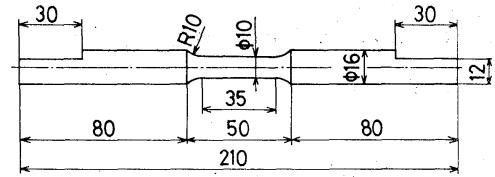

Fig. 1. Geometry of test piece.

Table II. Heat treatments and mechanical properties.

\begin{tabular}{c|c|c|c|c|c}
\hline Heat treatments & $\begin{array}{c}\sigma_{S} \\
(\mathrm{MPa})\end{array}$ & $\begin{array}{c}\sigma_{B} \\
(\mathrm{MPa})\end{array}$ & $\begin{array}{c}\delta \\
(\%)\end{array}$ & $\begin{array}{c}\phi \\
(\%)\end{array}$ & $H_{V}$ \\
\hline $865^{\circ} \mathrm{C} 30 \mathrm{~min} . \mathrm{A}$.C. & 397 & 615 & 31.6 & 57.2 & 181 \\
$600^{\circ} \mathrm{C} 30 \mathrm{~min} . \mathrm{F} . \mathrm{C}$. & & & & \\
\hline
\end{tabular}

的性質を Table II に示す.

疲労試験にはシェンク型曲げねじり疲労試験機を用 い，繰返し速度 $1200 \mathrm{cpm}$ で両振ねじり荷重を負荷 した."試験環境としてイオン交換水，イオン交換水に 重量パーセントで $0.5 \%$ と $3 \%$ になるよらに食塩を溶 解させた溶液中および大気中の 4 種類を設定し， $3 \%$

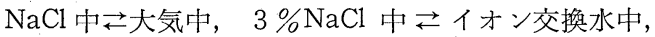
$3 \% \mathrm{NaCl}$ 中 $\rightleftarrows 0.5 \% \mathrm{NaCl}$ 中の二段環境疲労試験 った．な扔，液体環境中では試験片を液中に完全に浸 漬できるように試験片の周囲に環境槽を設け, 約 $5 l$ の試験液を約 $1.5 \mathrm{l} / \mathrm{min}$ で電子恒温装置との間を循環 させ， $25^{\circ} \mathrm{C} \pm 1{ }^{\circ} \mathrm{C}$ に保持した。 環境の切換光は第一段 環境中で所定の繰返し数を与えた後試験機を止めてパ イプの中の循環液を完全に抜きとり，フィルターも十 分に洗浄して，第一段環境の影響が残らないように十 分に注意した．試験片表面の腐食生成物はイオン交換 水中で超音波洗浄することにより除去した.

設定応力は Fig. 2 飞示す各環境中の $S-N$ 曲線より， 比較的都合のよい $145 \mathrm{MPa}$ にしたが，大気中の疲労 限以下になるので，大気中でも有限寿命になる 180

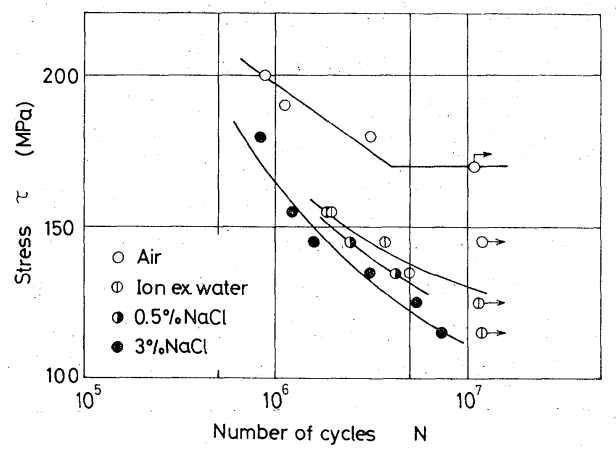

Fig. 2. $S-N$ curves.
$\mathrm{MPa}$ でる $3 \% \mathrm{NaCl}$ 中 $\rightarrow$ 大気中の二段環境試験を行っ た.

$$
3 \text { 記 号 }
$$

$N_{a}$ ：大気中の破断繰返し数

$n_{a} ：$ 二段環境下の大気中での繰返し数

$N_{i}$ ：イオン交換水中の破断繰返し数

$n_{i}$ : 二段環境下のイオン交換水中での繰返し数

$N_{n}: 0.5 \% \mathrm{NaCl}$ 中の破断繰返乙数

$n_{n}:$ 二段環境下の $0.5 \% \mathrm{NaCl}$ 中での繰返し数

$N_{s}: 3 \% \mathrm{NaCl}$ 中の破断繰返乙数

$n_{s}:$ 二段環境下の $3 \% \mathrm{NaCl}$ 中での繰返し数

\section{4 試験結果および考察}

\section{$4 \cdot 1$ 二段環境疲労試験}

Fig. 3〜 5 にそれぞれの二段環境下の疲労試験結果 を示す. 図の横軸は $3 \% \mathrm{NaCl}$ 中の繰返し数比で，縦 軸は総破断繰返し数である.

Fig. 3 の $3 \% \mathrm{NaCl}$ 中て大気中では応力が $145 \mathrm{MPa}$ の場合大気中の疲労限以下であるため, $3 \% \mathrm{NaCl}$ 中 $\rightarrow$ 大気中では $n_{s} / N_{s}=0.1$ 以下では総寿命が $10^{7}$ 以上と なるが，それ以上の $n_{s} / N_{s}$ では $3 \% \mathrm{NaCl}$ 中の寿命 $N_{s}$ より る低下する. とくに $n_{s} / N_{s}=0.2$ 付近で切換 光た場合, 寿命は最も低下し, Evans 5, Rollinsら, 北川ら，遠藤らの得た結果と同じ寿命低下の傾向を示 す。また，大気中でも有限の疲労寿命になるように設 定応力を $180 \mathrm{MPa}$ にした場合も $n_{s} / N_{s}=0.2$ 以上で 同様に寿命が $N_{s}$ よりる低下する．大気中 $\rightarrow 3 \% \mathrm{NaCl}$ 中の場合応力 $145 \mathrm{MPa}$ では大気中の疲労限以下であ るため環境を切換えた時点から $3 \% \mathrm{NaCl}$ 中の寿命だ け加算された時点で破断するはずであるが，実際は 3 $\% \mathrm{NaCl}$ 中よりも $20 \%$ 程度寿命の減少をひき括こして いる. 疲労限以下の応力であっても大気中で受けた疲 労のために腐食疲労が促進されたものと考えられる。

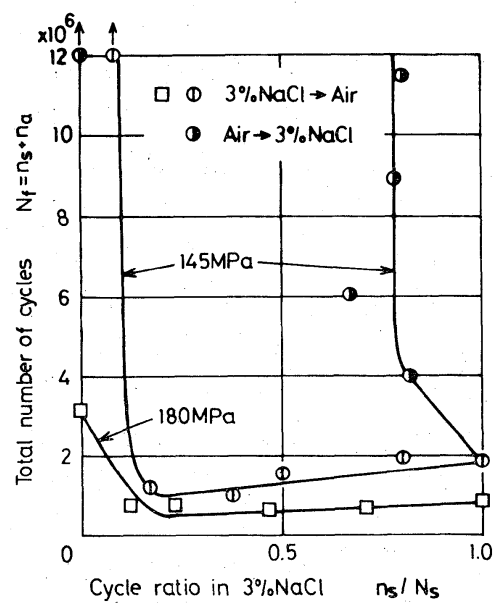

Fig. 3. The results of two-stage corrosionfatigue tests $(3 \% \mathrm{NaCl} \rightarrow$ In air). 


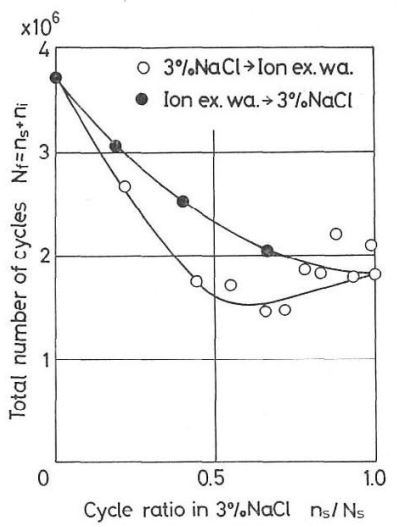

Fig. 4. The results of two-stage corrosionfatigue tests $(3 \% \mathrm{NaCl} \rightarrow$ ion exchanged water).

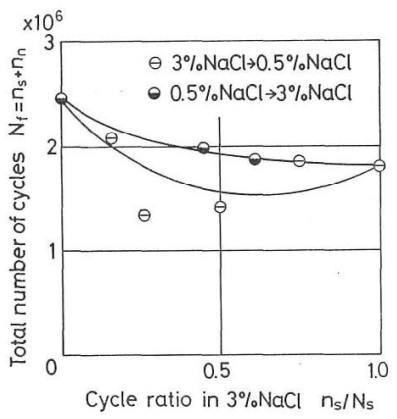

Fig. 5. The results of two-stage corrosionfatigue tests $(3 \% \mathrm{NaCl} \rightleftarrows 0.5 \% \mathrm{NaCl})$.

Fig. 4，5 は第二段環境としてそれぞれイオン交換 水， $0.5 \% \mathrm{NaCl}$ を用いた場合の結果でめる. Fig. 3 の 大気中に切換えた場合と同様， $3 \% \mathrm{NaCl}$ 中の及の寿 命より多低下寸る領域が存在する。逆にイオン交換水 中あるいは $0.5 \% \mathrm{NaCl}$ 中から $3 \% \mathrm{NaCl}$ 中に切换光た 場合の寿命は气れほど低下せず，ほぼマイナー則に従 5 .

これらの結果を $3 \% \mathrm{NaCl}$ 中の繰返し数比に対する 被害率 $D=1-n_{j} / N_{j}(j=a, i, n)$ で整理すると Fig. 6 のよらになる. ただし, 応力振幅 $145 \mathrm{MPa}$ では大 気中の疲労限以下となるが， $10^{7}$ の有限寿命として近 似した。図にはEvansら, Rollinsら, 岡本・北川, 遠 藤らの結果も同様に計算して示したが，本報告の $3 \%$ $\mathrm{NaCl}$ 中 大気中の結果と酒ぼ一致し, いずれの場合 も $n_{s} / N_{s}=0.2 \sim 0.3$ で被害率Dが80\%以上に達してい る。さらに，液中では濃淡いずれの環境が先でもマイ ナー則で定義される寿命よりも低下するが， $3 \% \mathrm{NaCl}$ 中から大気中へ切換克た曲線よりも内側になる。すな わら，種々の二段環境の寿命は常に $3 \% \mathrm{NaCl}$ 中 $\rightarrow 大$ 気中の曲線とマイナー則でとりかこまれた範囲内にあ る.

昭和 60 年10月

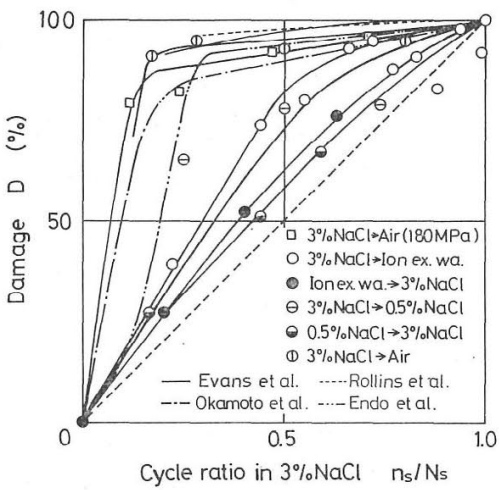

Fig. 6. Relation between cycle ratio in $3 \% \mathrm{NaCl}$ and damage.

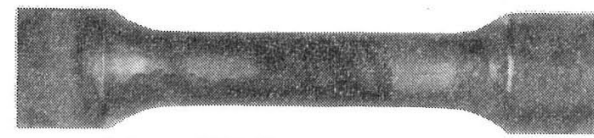

(a) In $3 \% \mathrm{NaCl}$

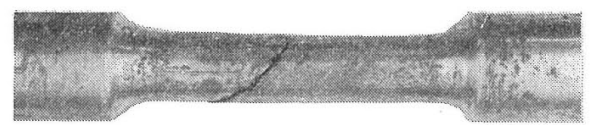

(b) In ion exchanged water

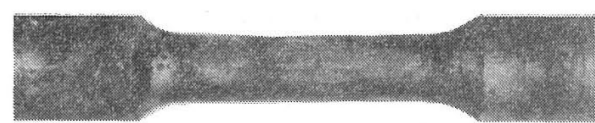

(c) $38 \mathrm{NaCl} \rightarrow$ Ion exchanged water, $\mathrm{n}_{\mathrm{S}} / \mathrm{N}_{\mathrm{S}}=0.44$

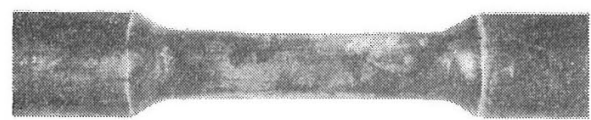

(d) Ion exchanged water $\rightarrow 3 \% \mathrm{NaCl}$, $\mathrm{n}_{\mathrm{S}} / \mathrm{N}_{\mathrm{S}}=0.5$

Fig. 7. Surface of test piece after fatigue test.

\section{$4 \cdot 2$ 表面の状態}

試験片の表面状態の一例学 Fig. 7 に示す. 図(a)は $3 \% \mathrm{NaCl}$ 中で破断した後の表面である. 腐食された 領域と腐食されない領域に大きく分かれている。この 傾向は $0.5 \% \mathrm{NaCl}$ 中でも観察され，既に報告してい る結果とも一致する. 図(b)はイオン交換水中で破断し た後の表面である，腐食された領域と腐食されない領 域が細かく分かれていて，そ狆が全体に広がっている。 図(c)は $3 \% \mathrm{NaCl}$ 中>イオン交換水中, $n_{s} / N_{s}=0.44$ で切换光たときの破断後の状態, また図(d)はイオン交 換水中 $\rightarrow 3 \% \mathrm{NaCl}$ 中, $n_{s} / N_{s}=0.50$ の場合である. 図(d)では，イオン交換水中の小さな腐食域と共に $3 \%$ $\mathrm{NaCl}$ 中のみの場合にみられた大さな腐食域が観察で きるが，図(c)ではイオン交換水中に切換觉てもイオン 交換水中特有の小さい腐食域が観察されない。これは $3 \% \mathrm{NaCl}$ 中を第一段環境に用いると，腐食が生じた 
部分ではさびがかなり付着しているので, 酸素の供給 があまりなく、イオン交換水中に切換光後も引続きつ ノードとして作用したためと考兄られる. 同様な状態 は $3 \% \mathrm{NaCl}$ 中‡ $0.5 \% \mathrm{NaCl}$ 中でる観察された. 以上 より，弱い腐食性環境中で発生した多数のき裂は強い 腐食性環境中でる一様に進展しらるが，強い腐食性環 境中から弱い腐食性環境中に切換兄た場合には大きく 分かれている非腐食域に新たに腐食ピットや微小き裂 が発生するよりも強い腐食性環境中で生じていたき裂
だけがさらに進展することが予想される

\section{$4 \cdot 3$ 試験片の断面で観察されるき裂}

すべての疲労試験を試験片の破断直前で中止して （停止装置の 作動が悪く破断したものも含も）軸方向 に切断し，断面き裂を観察した。 Fig. 8，9 はさ裂の 分布状態の一例である. 図中(A)は液面に近い側面，(B) はその反対側で，いずれも平行部 $35 \mathrm{~mm}$ の全域にわ たって観察した結果である。ただし，破断に関与した と考光られる最長き裂就よび $15 \mu \mathrm{m}$ 以下の微小き裂 は除外した. Fig. 8 (a)は $3 \% \mathrm{NaCl}$ 中の結 果で $400 \mu \mathrm{m}$ もの長いさ裂が数多く観察さ れるのに対し, Fig. 8 (c)のイオン交換水中 では汪とんどが $100 \mu \mathrm{m}$ 以下の短いき裂で ある. Fig. 8 (b)の $0.5 \% \mathrm{NaCl}$ 中では液面 に近い側のき裂個数は $3 \% \mathrm{NaCl}$ 中とあま り変らないが，反対側のき裂個数はイオン 交換水中よりも非常に少なく，き裂長さも 短い. 表面観察からも明らかなように 0.5 $\% \mathrm{NaCl}$ 中では腐食域之非腐食域が大きく 分かれていてたまたま両域にまたがるよう に切断されたためと考光られる.大気中で は破断面を形成する一本のき裂だけが検出 される。

二段環境下のき裂分布を Fig. 9 (a)～(c) に示す. 図(a)で， $3 \% \mathrm{NaCl}$ 中から大気中 一切換学ると， $3 \% \mathrm{NaCl}$ 中で発生，進展 していたき裂は切換光後も短いき裂のまま である.特定の 1 本のき裂だけが大気中で 進展して破断導いたものと考党られる. 図(b)の $3 \% \mathrm{NaCl}$ 中からイオン交換水中に 切換觉ると, Fig. 8 (c)のように多数のき裂 が発生するが，イオン交換水中ではあまり 進展しないので無視される程度の長さであ る. 反面, 前段の $3 \% \mathrm{NaCl}$ 中で生じてい たき裂のらち長いき裂が集中的に進展した ことを物語っている。逆に図(c)のイオン交 換水中から $3 \% \mathrm{NaCl}$ 中に切換兄られると, イオン交換水中で発生していた多数のき裂 が $3 \% \mathrm{NaCl}$ 中で加速されるので，き裂個 数が多く, しかも長いき裂が観察されたも のと考觉られる。

Fig. 10〜12 は二段環境下で行われたす べての疲労試験片の破断後のき裂分布図か ら単位長さ当りのき裂個数とき裂長さの上 限値, 下限值 (15 $\mu \mathrm{m}$ 以下無視) 拉よび平 均值を求め対数目盛で示したものである. 図中の破線は $3 \% \mathrm{NaCl}$ 中のそれぞれの $n_{s} / N_{s}$ で試験を停止してき裂分布を調べた

Fig. 8. Axial crack distribution after fatigue test, (a) in $3 \% \mathrm{NaCl}$ (b) in $0.5 \% \mathrm{NaCl}$ and (c) in ion exchanged water. 


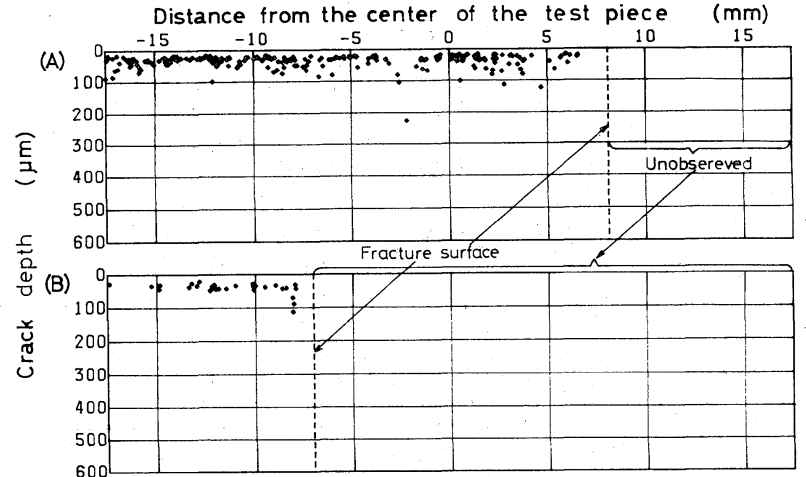

(a) $\tau=145 \mathrm{MPa}, 3 \% \mathrm{NaCl} \rightarrow \ln$ air $\mathrm{ns} / \mathrm{Ns}=0.50, \mathrm{Nf}=1.552 \times 10^{6}$

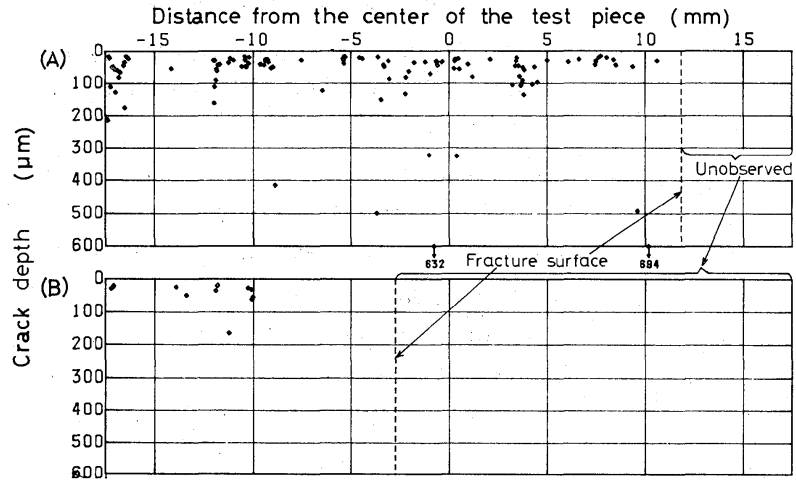

(b) $\tau=145 \mathrm{MPa}, 3 \% \mathrm{NaCl} \rightarrow$ Ion ex. water, $\mathrm{ns} / \mathrm{Ns}=0.44, \mathrm{~N} f=1.752 \times 10^{6}$

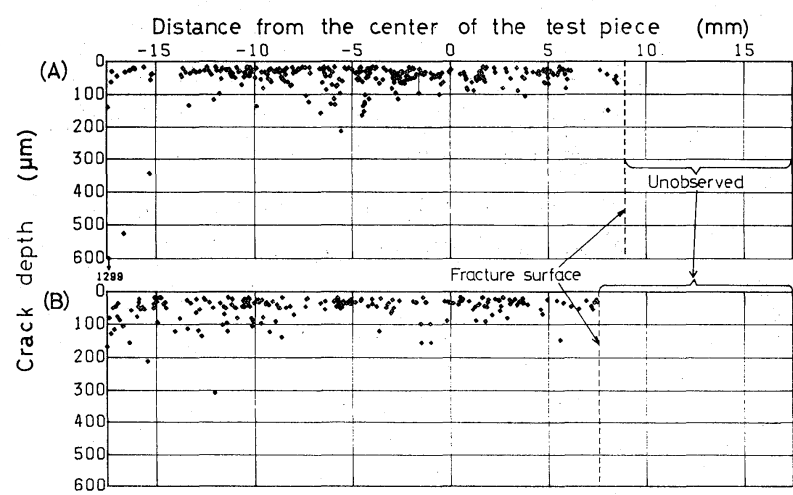

(c) $\tau=145 \mathrm{MPa}$, Ion ex. water $\rightarrow 3 \% \mathrm{NaCl}, \mathrm{ns} / \mathrm{Ns}=0.40, \mathrm{Nf}=2.521 \times 10^{6}$

Fig. 9. Axial crack distribution after two-stage corrosion-fatigue test, (a) $3 \% \mathrm{NaCl} \rightarrow$ in air, (b) $3 \% \mathrm{NaCl} \rightarrow$ ion exchanged water and (c) ion exchanged water $\rightarrow 3 \% \mathrm{NaCl}$.

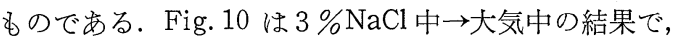
切換光後き裂個数も平均き裂長さむほとんぞ增加しな い. $3 \% \mathrm{NaCl}$ 中で発生していたき裂の中で相当長い き裂の中から唯一的に進展したものと考兄られる。

Fig. 11 は $3 \% \mathrm{NaCl}$ 中 飞イオン交換水中の結果で, $n_{s} / N_{s} \fallingdotseq 0.45$ 以前に $3 \% \mathrm{NaCl}$ 中から イオン交換水中 に切換光ると, 切換光後もき裂個数, 平均き裂長さは
著しく增加する．イオン交換水中になって 短いき裂が数多く発生すると同時に $3 \%$ $\mathrm{NaCl}$ 中で生じていたき裂む相当進展する ためである. しかし， $n_{s} / N_{s}=0.45$ 以降に 切換觉ると，き裂個数も平均き裂長さもほ とんぞ増加しない。そのために $3 \% \mathrm{NaCl}$ 中 $\rightarrow$ 大気中と同様長いき裂が選択的に進展 するよらになり破断寿命も $3 \% \mathrm{NaCl}$ 中の みの場合よりも低下したものと考兄られる. Fig. 11 をより詳細比調べると $3 \% \mathrm{NaCl}$ 中 ーイオン交換水中では切換光後もき裂長さ がやや增加して拈り，そのため Fig. 6 に 示す損傷曲線が $3 \% \mathrm{NaCl} \rightarrow$ 大気中の曲線 の内側に入ったものと考兄られる，逆に， イオン交換水中から $3 \% \mathrm{NaCl}$ 中に切換光 た場合には $3 \% \mathrm{NaCl}$ 中 $\rightarrow$ オン交換水中 に比べ，観察されるき裂個数が多くなり， 平均き裂長さも切換光時期によらず増加す る. 切換兄後もき裂が数多く発生すると同 時にイオン交換水中で発生していたさ裂は $3 \% \mathrm{NaCl}$ 中でいずれも一様に進展したた めと考壳られ，このため破断寿命も比較的 マイナー則に近い值を示したものと推察さ 孔る. Fig. 12 の $3 \% \mathrm{NaCl}$ 中セ0. $5 \% \mathrm{NaCl}$ 中でも同じような傾向が認められる.

\section{5 結言}

本報では， $3 \% \mathrm{NaCl}$ 中 $\rightleftarrows$ 大気中， $3 \%$ $\mathrm{NaCl}$ 中セイオン交換水中, $3 \% \mathrm{NaCl}$ 中 $\rightleftarrows 0.5 \% \mathrm{NaCl}$ 中の二段環境下で永じり腐 食疲労試験を行い，また試験片軸方向断面 のき裂観察を通じて検討を加えた結果, 次 の諸点が明らかになった。

(1) $3 \% \mathrm{NaCl}$ 中から大気中に切換元た 場合はこれまでの報告と同様 $3 \% \mathrm{NaCl}$ 中 のみの寿命よりも低下したが， $3 \% \mathrm{NaCl}$ 中 $\rightarrow$ イン交換水中, $3 \% \mathrm{NaCl}$ 中 $\rightarrow 0.5 \%$ $\mathrm{NaCl}$ 中の場合でも同様の傾向が認められ る. しかし, 損傷曲線で比較したとき，こ れらの結果は $3 \% \mathrm{NaCl}$ 中 $\rightarrow$ 大気中の内側 飞存在していて前段の損傷効果はそれほど 大きくならない。

（2）腐食性の弱い環境から腐食性の強い環境に切換 光た場合は大きな寿命低下は示さずほぼマイナー則に 従う。

（3）強い腐食性環境中で発生した数多くのき裂は， 弱い腐食性環境に切換えると特定の長く進展していた き裂だけが一層進展するよらになり，そのために寿命 も著しく短くなる。一方, 弱い腐食性環境中で発生し 


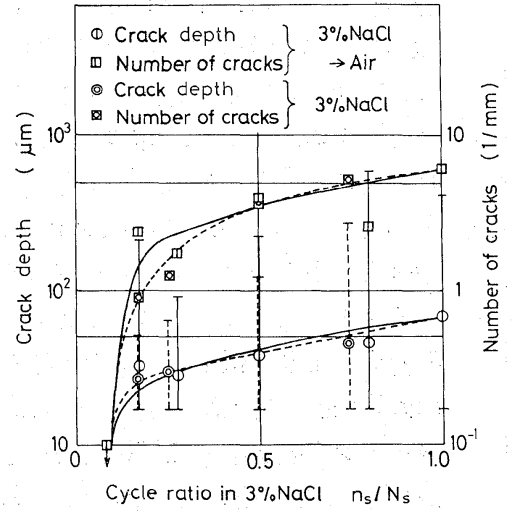

Fig. 10. Depth and number of cracks after twostage corrosion-fatigue tests $(3 \% \mathrm{NaCl} \rightleftarrows$ in air $)$.

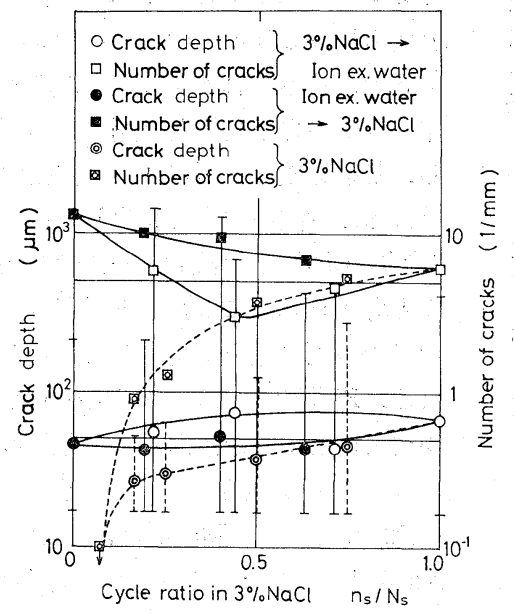

Fig. 11. Depth and number of cracks after twostage corrosion-fatigue tests $(3 \% \mathrm{NaCl} \rightleftarrows$ ion exchanged water).

た多数のき裂は強い腐食性環境中に切換えても一様に 進展するために，寿命もほぼマイナー則に近い值を示 す. （昭和59年11月10日 第17回疲労シンポジウムにて講演）

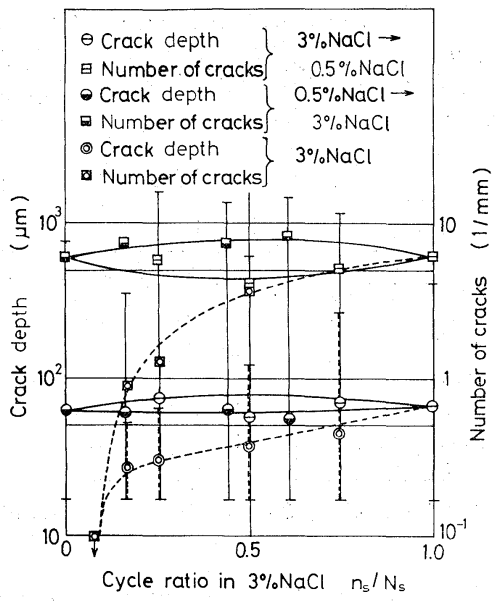

Fig. 12. Depth and number of cracks after twostage corrosion-fatigue tests $(3 \% \mathrm{NaCl} \rightleftarrows 0.5 \%$ $\mathrm{NaCl})$.

\section{参 考 文 献}

1) D. J. McAdam, Jr., Proc. Am. Soc. for Test. Mat., 28, 117 (1928).

2) U. R. Evans and M. T. Simnad, Proc. Roy. Soc. [A], 188, 372 (1974).

3) M.T. Simnad and U.R. Evans, Jour. Iron and St. Inst., 531 (1947).

4) V. Rollins, B. Arnold and E. Lardner, Metallurgia, 75, 149 (1967).

5）岡本舜三，北川英夫，日本機械学会誌， 62，204 (1959).

6) H. Kitagawa, Exp. Mechanics, 7, 28 (1967).

7) 遠藤吉郎, 駒井謙治郎, 中室直之, 日本機械学会論文集, 35, 2154 (1969).

8）石原外美, 塩沢和章, 宮尾嘉寿, 材料，33，901 (1984).

9）岡田庸敬，服部修次，日本機械学会論文集，A-49, 685 (1983). 